\title{
Local synovial synthesis of oligoclonal measles virus antibodies and of smooth muscle antibodies in a case of atypical rheumatoid arthritis
}

\author{
B. VANDVIK, O. J. MELLBYE, AND E. NORRBY
}

From the Institute of Immunology and Rheumatology, Rikshospitalet, and Department of Neurology, Ulleva sykehus, University of Oslo, Norway, and Department of Virology, Karolinska Institutet, School of Medicine $\frac{0}{5}$ Stockholm, Sweden

SUMMARY A patient with atypical rheumatoid arthritis (RA) and local synovial synthesis of oligoclonal IgG in an arthritic knee joint is described. Measles virus-specific antibodies isolateф from the synovial fluid (SF) were carried by oligoclonal IgG proteins but constituted only a fraction. of the total oligoclonal IgG of the SF. Smooth muscle antibodies were markedly increased in the SF compared with the serum and were associated with an electrophoretically restricted fraction of IgG. The results indicate that a local synovial synthesis of measles virus-specific antibodies and of smooth muscle antibodies occurred within the affected joint in our patient.

An association between various arthritides and certain connective tissue diseases and persistent virus infections has been suggested in recent years (Kalliomäki and Halonen, 1975). Arthritis may occur in connection with rubella virus (Yanez et al., 1966), and hepatitis B virus infections (Smith and Sanford, 1967; Albert, 1971). Raised levels of virus antibodies, predominantly against measles virus, have been reported in the sera or joint fluids of patients with rheumatoid arthritis (RA) and other connective tissue disorders (Phillips and Christian, 1970, 1973; Hurd et al., 1970, 1972; Hollinger et al., 1971; Kalliomäki and Halonen, 1972; Kalliomäki et al., 1975). Synthesis of immunoglobulins, mainly IgG, within affected joints in patients with RA is well documented (Smiley et al., 1968) and includes local synthesis of rheumatoid factor of both IgG and IgM type (Hannestad and Mellbye, 1967; Munthe and Natvig, 1972). Attempts to show a local synthesis of viral antibodies have, however, given negative results (Cremer et al., 1974).

We describe a patient with seronegative RA in whom a distinct oligoclonal IgG pattern of the synovial fluid was observed. We found evidence of synovial synthesis of smooth muscle antibody (SMA) and of oligoclonal measles virus-specific antibodies in this patient.

Accepted for publication December 31, 1976

Correspondence to Dr. B. Vandvik, Institute of Immunology and Rheumatology, Rikshospitalet University Hospital, F. Qvams gate 1, Oslo, 1, Norway

\section{Patient}

Synovial fluid (SF) from the left knee joint and serum of the patient (male, 60 years old) wer\% selected for the study. The SF sample showed distinct oligoclonal IgG pattern, identified during of study of RA patients who had undergone synos vectomy (Mellbye et al., 1976). The joint disease hat begun when he was 26 years old and gradually worsened, interrupted by periods of remission. Signs of arthritis were confined mainly to knee and ankle joints but were also observed in the proximas interphalangeal joints for shorter periods. Synoê vectomies of the left knee joint were performed in 1968 and 1975 and showed massive villous hypers trophy of the synovium, erosion of the tibial edgess and partial destruction of the cartilage with pannus formation. Histological examination showed chronia villous synovitis with infiltration by lymphocytes and plasma cells. Tests for rheumatoid factor in seruno have been consistently negative. Because of this, and the predominant involvement of large joints, the disease was classified as an atypical form of RA.

A slight effusion was present in the left kneक when the SF samples were obtained. Laboratory examination of the SF, including cell count, assess ${ }^{D}$ ment of turbidity and viscosity, and determination of coagulability, showed changes consistent with mild arthritis.

Serum and SF samples from another patient witb RA (female, 55 years old) with a polyclonal Ig 
pattern of the SF were used as control materials. Repeated tests for rheumatoid factor in this patient showed negative or doubtful positive reactions. Otherwise she had a typical RA with involvement of both large and small joints, and had undergone several synovectomies, including synovectomy of the knee joint from which SF samples for the present study were drawn.

\section{Methods}

\section{SERUM AND SYNOVIAL FLUID}

Samples of serum and SF were obtained simultaneously. Blood and SF for complement studies were drawn with $0.02 \mathrm{M}$ EDTA and the SF was centrifuged at $1500 \mathrm{~g}$ for 10 minutes in order to remove cells before freezing at $-70^{\circ} \mathrm{C}$. The SF samples were treated with hyaluronidase (Penetrase, Leo, Copenhagen) as described by Hedberg (1967) before further examination.

\section{VIRUS ANTIGENS}

Measles cells associated virus (CAV) and purified extracellular virus (PV) antigens were prepared from Vero cell cultures infected with the LEC strain of measles virus as described elsewhere (Norrby and Hammarskjöld, 1972). Control antigens included purified extracellular virus and cell harvests from Vero monolayer cultures infected with Sendai virus and Newcastle disease virus. Mumps virus (local strain) was propagated in the chorioallantoic membrane of embryonated hen's egg.

\section{PROTEIN CHARACTERIZATION}

Quantitation of IgG, IgA, IgM, complement factors $(C 3,4,5)$, and albumin was carried out by single radial immunodiffusion (Mancini et al., 1965). Analytical electrophoresis and preparative electrophoresis in agarose gel were performed as described previously (Vandvik and Norrby, 1973).

\section{SEROLOGICAL TESTS}

Rheumatoid factor was tested as previously described (Mellbye and Natvig, 1970) Antinuclear antibodies, antimitochondrial antibodies, and smooth muscle antibodies were determined in indirect immunofluorescence tests. Anti-DNA antibody was determined by a counter-current electrophoresis method.

Measles virus haemagglutination-inhibiting (HI), haemolysis-inhibiting (HLI), and nucleocapsid complement-fixing (NC-CF) antibodies were determined as described previously (Norrby and Gollmar, 1972). Immunoelectrophoresis was used as a general method for the characterization of gel precipitating antibodies to measles virus, using measles CAV antigen. Antibodies to adeno, rubella, mumps'
Sendai and herpes simplex type I viruses were determined as described previously (Norrby et al., 1974).

\section{ISOLATION OF VIRUS ANTIBODIES}

Samples were absorbed with virus antigens, whereafter virus-antibody precipitates were dissociated by incubation with buffers of increasing acidity (Vandvik et al., 1976). Briefly, each sample was mixed with a fixed amount of antigen and incubated overnight at $4^{\circ} \mathrm{C}$. The mixture was centrifuged at $20000 \mathrm{~g}$ for 30 minutes. The supernate was concentrated to a volume corresponding to that of the original sample. The sediment was washed with phosphate-buffered saline and eluted with $10 \mathrm{ml}$ volumes of buffer at increasingly acid $\mathrm{pH}(\mathrm{pH} \mathrm{4,3}$, and 2). The eluates were immediately neutralized with Tris salt, dialysed overnight, and concentrated by vacuum dialysis to $100 \mu$ l each. Bovine serum albumin was added at a final concentration of $0 \cdot 1 \%$ in order to stabilize the eluted proteins.

\section{Results}

PROTEINS IN SERUM AND SF

The serum/SF ratios of IgG in the patient was lower than the corresponding ratios of IgA, IgM, and albumin (Table 1). Thus there was a relative

Table 1 Proteins and antibody activities of serum and synovial fluid from the patient and from the control patient

\begin{tabular}{|c|c|c|c|c|c|c|}
\hline & \multicolumn{3}{|c|}{ Patient } & \multicolumn{3}{|c|}{ Control } \\
\hline .. & \multicolumn{2}{|c|}{ Serum $S F$} & \multirow[t]{2}{*}{$\begin{array}{l}\text { Ratio of } \\
\text { serum } / S F\end{array}$} & \multicolumn{2}{|c|}{ Serum SF } & \multirow{2}{*}{$\begin{array}{l}\begin{array}{l}\text { Ratio of } \\
\text { serum } / S F\end{array} \\
\end{array}$} \\
\hline Proteins $(\mathrm{g} / \mathrm{l})$ & & & & & & \\
\hline IgG & 14 & 15 & 0.9 & 12 & 7 & $1 \cdot 7$ \\
\hline IgA & $2 \cdot 2$ & 0.8 & $2 \cdot 7$ & $1 \cdot 7$ & $1 \cdot 8$ & 0.9 \\
\hline IgM & $0 . \overline{8}$ & $0 \cdot 3$ & $2 \cdot 6$ & 0.5 & 0.5 & 1.0 \\
\hline Albumin & 41 & 21 & $1 \cdot 9$ & 44 & 53 & 0.8 \\
\hline Ratio IgG/albumin & $0 \cdot 34$ & 0.71 & & $0 \cdot 27$ & $0 \cdot 13$ & \\
\hline C3 & $1 \cdot 1$ & 0.3 & $3 \cdot 7$ & ND & ND & \\
\hline C4 & 460 & 60 & $7 \cdot 7$ & ND & ND & \\
\hline $\begin{array}{l}\text { C5 } \% \text { of normal } \\
\text { serum }\end{array}$ & 100 & $<10$ & $>10$ & ND & ND & \\
\hline Antibodies & & & & & & \\
\hline $\begin{array}{l}\text { SMA } \\
\text { Measles virus }\end{array}$ & 32 & 256 & $0 \cdot 1$ & $<8$ & $<8$ & \\
\hline HI & 640 & 320 & 2 & 320 & 1280 & 0.2 \\
\hline HLI & 160 & 320 & 0.5 & 1280 & 640 & 2 \\
\hline NC-CF & 1280 & 2560 & 0.5 & 40 & 40 & 1 \\
\hline Mumps virus HI & 20 & 20 & 1 & $<4$ & $<4$ & \\
\hline Sendai virus $\quad$ HI & 1280 & 640 & 2 & 8 & 4 & 2 \\
\hline $\begin{array}{l}\text { Rubella virus HI } \\
\text { Herpes simples }\end{array}$ & 16 & 16 & 1 & $<8$ & $<8$ & \\
\hline virus type 1 HA & 1280 & 1280 & 1 & 1280 & 640 & 2 \\
\hline Adenovirus $\quad H E$ & 320 & 160 & 2 & 40 & 40 & 1 \\
\hline
\end{tabular}

C3, C4, C5 = complement factors 3, 4, 5; SMA = smooth muscle antibody; $\mathrm{HI}=$ haemagglutination-inhibition; $\mathrm{HLI}=$ haemolysis-inhibition; $\mathbf{N C}-\mathbf{C F}=$ nucleocapsid complement-fixation; $\mathbf{H A}=$ haemadsorption; $\mathrm{HE}=$ haemagglutination-enhancing; $\mathrm{ND}=$ not done. 
increase of IgG in the SF compared with serum. The levels of complement $\mathrm{C} 3, \mathrm{C} 4$, and $\mathrm{C} 5$ were all markedly lower in the SF than in the serum, and the serum/SF ratios for these proteins were higher than for albumin (Table 1). This was consistent with a local consumption and activation of complement in the joint (Hedberg, 1967).

Electrophoretic analysis showed four homogeneous protein bands migrating with the intermediate and cathodal gamma globulin fraction of the SF (Fig. 1a). The bands were identified as IgG and were associated with an electrophoretically uneven distribution of $\kappa$ and $\lambda$ determinants, as described elsewhere (Mellbye et al., 1976). The gamma globulin fraction of the serum showed a polyclonal pattern, but a weak band of IgG corresponding to one of the bands present in the SF was discernible.

No relative increase of $\mathrm{IgG}$ in the SF compared with serum was observed in the control patient (Table 1), and no homogeneous IgG proteins were detected (Fig. 2a).

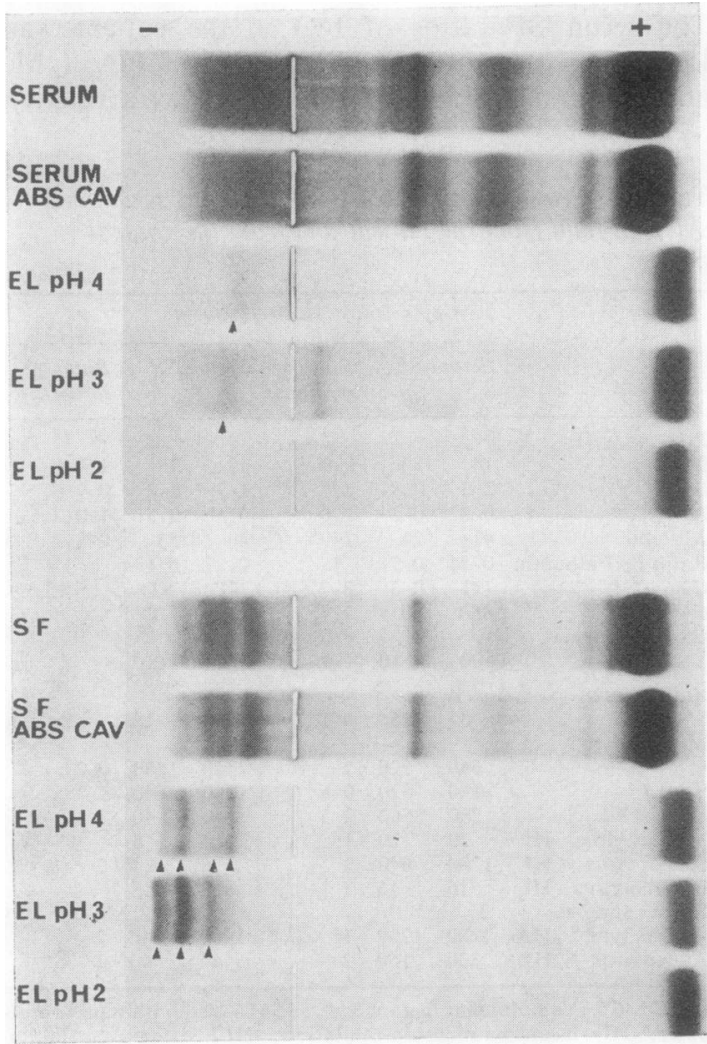

(a)
AUTOANTIBODIES IN SERUM AND SF

SMA activities were detected in both serum and $S \dot{E}$ from the patient, and the SF titre of SMA was times higher than in serum (Table 1). Indire immunofluorescent tests with class-specific antiser? showed that SMA activity of both samples was associated exclusively with IgG.

The electrophoretic distribution of SMA activity in the SF was studied in experiments where agarose gel strips containing electrophoretically separated IgG were layered on rat ventricle cryostat sections and incubated for 30 minutes, after which th sections were washed and examined in indire immunofluorescence. Repeated experiments showeg a restriction of SMA activity in the SF to the slow IgG fraction, corresponding to the position of twe of the basic bands of IgG. This was in contrast tO findings in sera with high titres of SMA from patients with hepatitis, where an electrophoretically heterogeneous distribution within the slow an

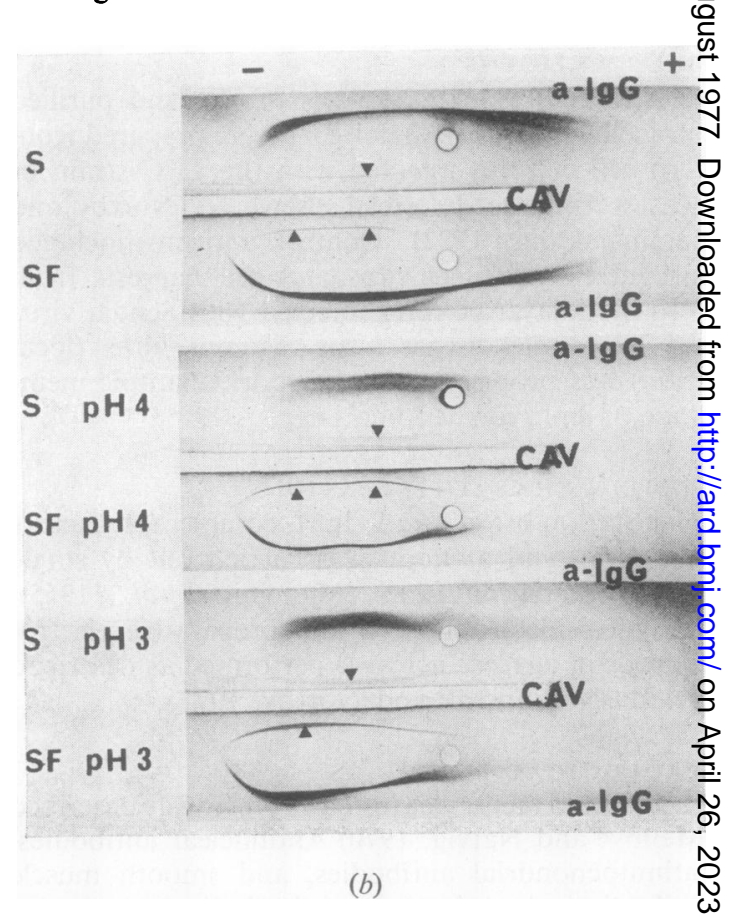

Fig. 1 (a) Agarose electrophoresis of serum and synovig fluid $(S F)$ from the patient before and after absorption 0 with measles cell associated virus $(C A V)$ antigen, and of $\bar{\varnothing}$

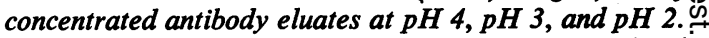
The positions of bands of IgG are marked by arrowheadso (b) Immunoelectrophoresis of serum $(S)$ and $S F$ and of concentrated antibody eluates at $\mathrm{pH} 4$ and $\mathrm{pH} 3$ from serum and $S F$ shown in $(a)$. The troughs were filled with antiserum to $\operatorname{IgG}(a-I g G)$ and with measles $C A V$ antigen. The arrowheads denote measles nucleoprotein (NP) antibodies. 


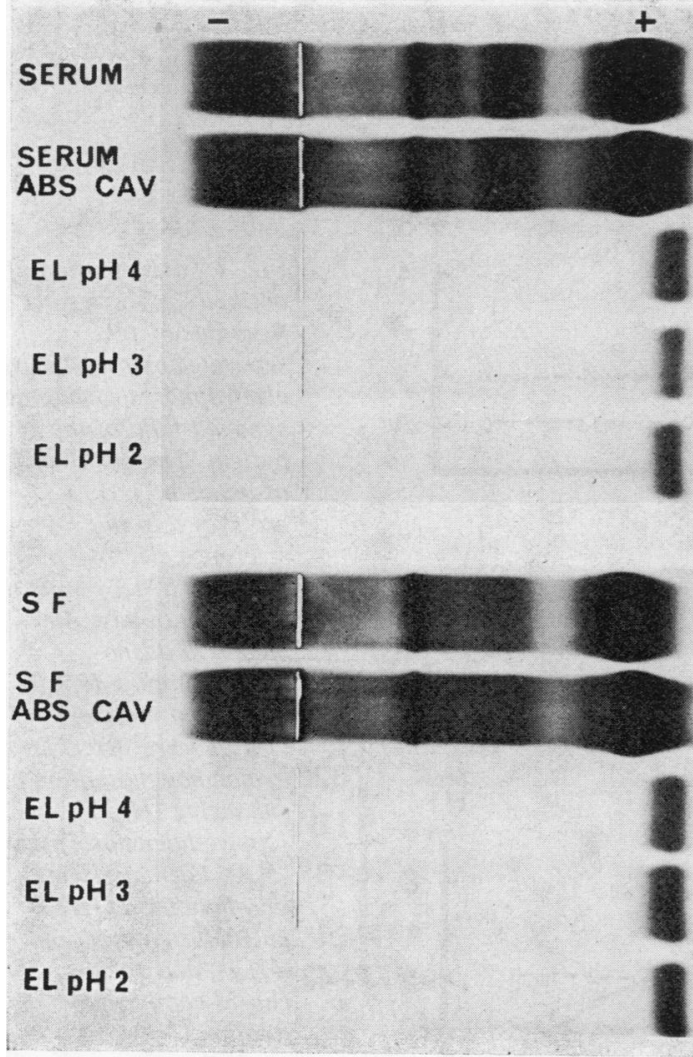

(a)

intermediate IgG fraction was seen. The restriction of SMA activity in the SF was confirmed by analysis of SMA in fractions of IgG separated by preparative electrophoresis of the SF (Fig. 3).

Tests for antinuclear antibodies, antimitochondrial antibodies, anti-DNA antibody, and the rheumatoid factor in serum and SF from the patient and the control patient were negative. No SMA activity was detected in the samples from the control (Table 1).

VIRUS ANTIBODY ACTIVITIES OF SERUM AND SF Relatively high levels of measles HI, HLI, and NC-CF antibody activities were detected in both serum and SF from the patient and from the control. The serum/SF ratios of these antibodies were not significantly different from the corresponding ratios of other virus antibodies (Table 1).

Immunoelectrophoretic characterization of measles antibodies to CAV antigen showed one single antibody precipitate arc in both serum and SF from the patient, identified as antibody to measles virus nucleoprotein (Vandvik and Degré, 1975). The nucleoprotein antibody activity migrated with the

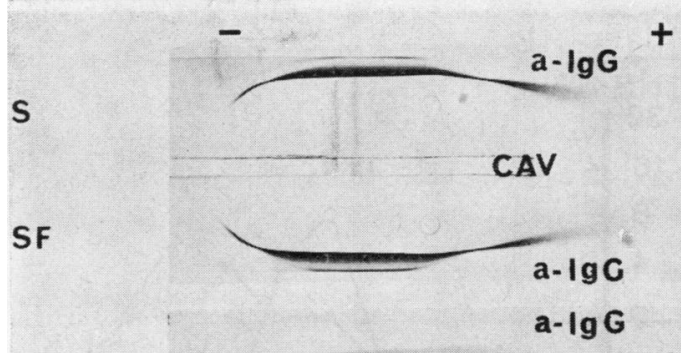

S p 4

CAV

\section{SF pH 4}

$a-\lg G$

$5 \quad \mathrm{pH} 3$

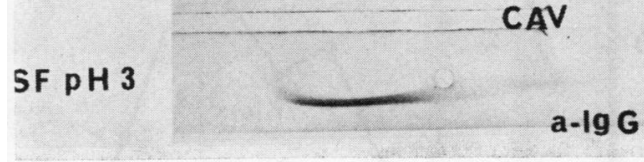

(b)

Fig. 2 (a) Aga:ose electrophoresis of serum and synovial fluid $(S F)$ from the control patient before and after absorption with measles cell associated virus $(C A V)$ antigen, and of concentrated antibody eluates at $\mathrm{pH} 4$, $p H 3$, and $p H$ 2. (b) Immunoelectrophoresis of serum (S) and $S F$ and of concentrated antibody eluates shown in $(a)$. The troughs were filled with antiserum to $\operatorname{IgG}(a-\operatorname{IgG})$ and with measles CAV antigen.

basic and intermediate IgG fraction and was stronger in the SF than in the serum. The antibody precipitate of the SF was bideflected, suggesting accumulations of antibody to measles nucleoprotein within two separate and electrophoretically restricted IgG mobility zones (Fig. 1b). No precipitating measles nucleoprotein antibody was detected in the serum or SF from the control patient (Fig. $2 b$ ).

The distribution of antibody activities against different measles virus antigens and to herpes simplex virus type 1 and adenovirus was studied in fractions of IgG separated by preparative electrophoresis of the SF from the patient (Fig. 3). Adenovirus antibodies, although present in low concentrations, appeared in highest titres in fractions containing a maximum amount of IgG. Measles and herpes virus antibodies showed a different distribution indicating their association with IgG occurring within restricted mobility zones. Measles HI and nucleocapsidspecific antibodies showed significantly different distributions. A similar analysis of the SF from the control patient showed a distribution of measles and 

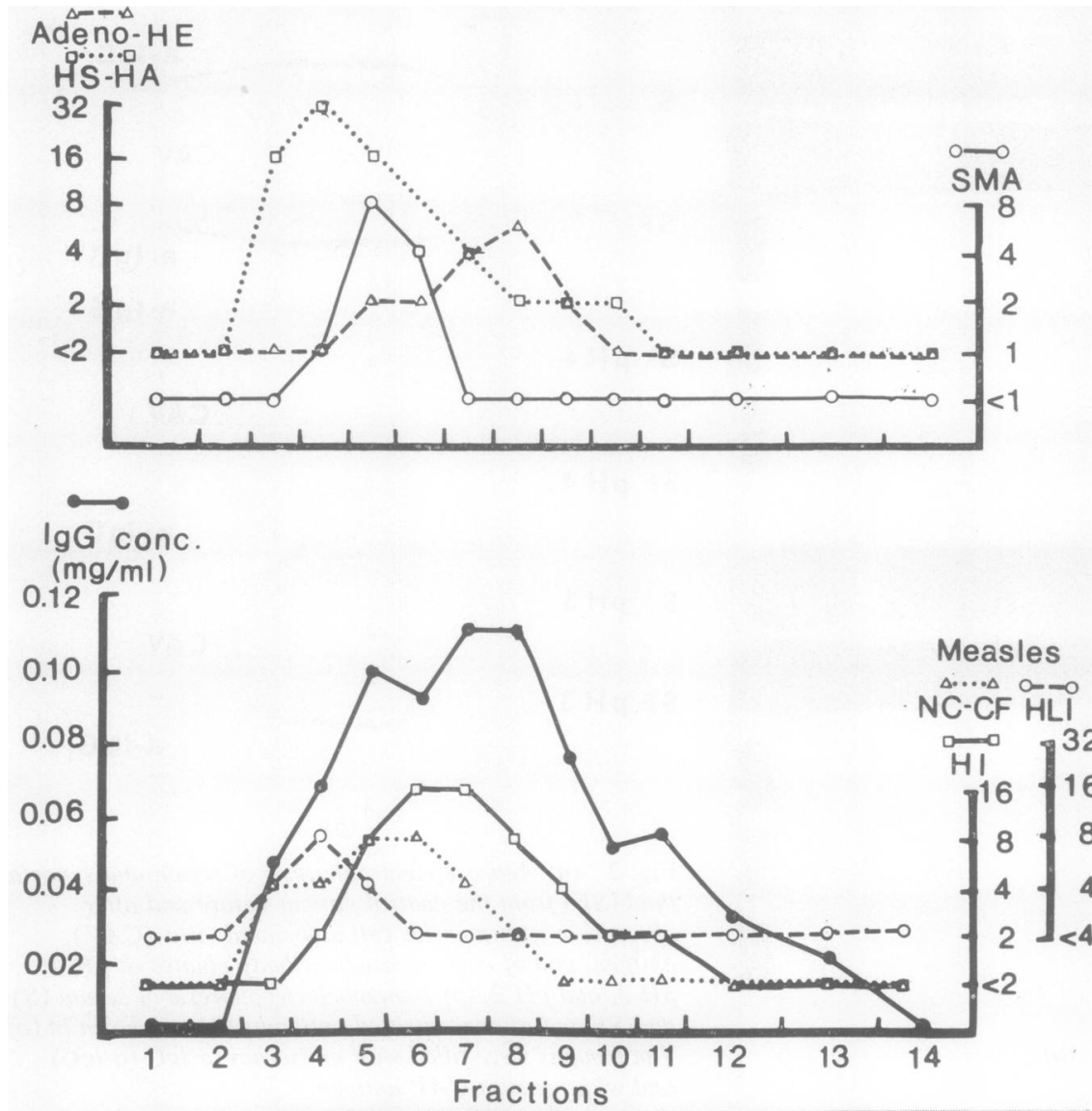

Fig. 3 Distribution of antibody activities in fractions of IgG separated by preparative electrophoresis from th? synovial fluid of the patient. The positions of bands of $\operatorname{Ig} G(\mathbf{\Lambda})$ are shown in the reference electrophoresis. $S M A=$ smoot muscle antibody. Antibodies to adeno-, herpes simplex type 1(HS), and measles viruses were determinest by haemagglutination- $\vec{\theta}$ enhancing (HE), passive haemabsorption (HA), haemagglutination-inhibition $(H I)$, haemolysis-inhibition (HLI), and nucleocapsid-complement fixation (NC-CF) methods.

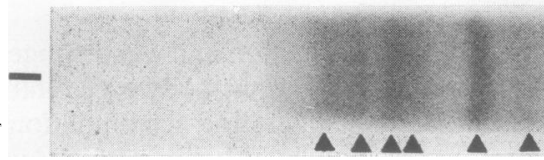

herpes simplex virus antibodies correlating with the polyclonal pattern of IgG.

\section{ISOLATION OF MEASLES VIRUS-SPECIFIC ANTI- BODIES}

Samples of serum and SF from the patient, each in a volume containing a total amount of $20 \mathrm{mg} \mathrm{IgG}$, were absorbed with a fixed amount of measles CAV antigen. Virus antibodies were eluted at $\mathrm{pH} \mathrm{4,} \mathrm{pH} \mathrm{3,}$ and $\mathrm{pH} 2$, as described in the Methods section.

A decrease in measles antibody activity was observed after absorption of both serum and SF, while the levels of other virus antibodies remained essentially unchanged (Table 2). Electrophoretic analysis showed no decrease of the gamma globulin fraction of serum or SF after measles virus absorption (Fig. 1a).
The acid eluates contained significant levels of measles antibodies while other virus antibodies werê not detected. The levels of NC-CF antibody in the antibody eluates from the SF were higher than in eluates from the serum, whereas no significan differences were observed for HI and HLI antibodies (Table 2).

The dominant class of Ig in the antibody eluates was IgG. The eluates from the SF contained marked higher levels of IgG than the eluates from the serur (Table 2). Electrophoretic analysis showed severap homogeneous gamma-bands in the antibody eluates from the SF. They occurred mainly in eluates $a \overline{0}$ pH 4 and pH 3, but two weak zones were detected also in the $\mathrm{pH} 2$ eluate (Fig. 1a).

The homogeneous protein bands were identified as IgG proteins by immunoelectrophoresis (Fig. 1b) 
Table 2 Absorption and isolation of measles virus antibodies from serum and synovial fluid $(S F)$ of the patient*

\begin{tabular}{|c|c|c|c|c|c|c|}
\hline & & \multirow{3}{*}{$\begin{array}{l}I g G \\
(g / l)\end{array}$} & \multicolumn{4}{|c|}{ Antibodies } \\
\hline & & & \multicolumn{3}{|c|}{ Measles virus } & \multirow{2}{*}{$\begin{array}{l}\text { Adenovirus } \\
\mathrm{HE}\end{array}$} \\
\hline & & & $H I$ & $H L I$ & $N C-C F$ & \\
\hline \multicolumn{2}{|c|}{$\begin{array}{l}\text { Serum } \dagger \\
\text { Serum absorbed }\end{array}$} & $5 \cdot 1$ & 320 & 320 & 80 & 160 \\
\hline \multicolumn{2}{|c|}{$\begin{array}{l}\text { Serum absorbed } \\
\text { measles CAV }\end{array}$} & $5 \cdot 0$ & $<40$ & 160 & $<5$ & 160 \\
\hline Eluate & pH 4 & 0.43 & 80 & 160 & 80 & $<10$ \\
\hline Eluate & pH 3 & 0.60 & 640 & 320 & 80 & $<10$ \\
\hline Eluate & pH 2 & 0.06 & 160 & 80 & 10 & $<10$ \\
\hline$S F \dagger$ & & $5 \cdot 4$ & 160 & 320 & 80 & 160 \\
\hline \multicolumn{7}{|l|}{ SF absorbed } \\
\hline \multicolumn{2}{|c|}{ measles CAV } & $5 \cdot 3$ & 20 & 320 & 20 & 160 \\
\hline Eluate & pH 4 & $1 \cdot 35$ & 160 & 160 & 320 & $<10$ \\
\hline Eluate & pH 3 & 1.75 & 640 & 160 & 160 & $<10$ \\
\hline Eluate & pH 2 & 0.50 & 160 & 40 & 80 & $<10$ \\
\hline \multicolumn{7}{|c|}{ Reabsorbed $\S$ measles } \\
\hline PV & & $5 \cdot 0$ & $<20$ & 80 & 5 & 320 \\
\hline Eluate & pH 4 & 0.80 & $<20$ & 160 & 20 & $<10$ \\
\hline Eluate & $\mathrm{pH} 3$ & 0.61 & 80 & 320 & 40 & $<10$ \\
\hline Eluate & pH 2 & 0.01 & $<20$ & $<20$ & $<10$ & $<10$ \\
\hline \multicolumn{7}{|c|}{ Reabsorbed $\S$ measles } \\
\hline CAV & & $4 \cdot 9$ & $<2$ & $<5$ & $<2$ & 320 \\
\hline Eluate & pH 4 & 0.48 & $<10$ & 80 & $<10$ & $<10$ \\
\hline Eluate & pH 3 & 0.55 & 320 & 640 & $<10$ & $<10$ \\
\hline Eluate & pH 2 & 0.03 & $<10$ & $<20$ & $<10$ & $<10$ \\
\hline \multicolumn{7}{|c|}{ Reabsorbed $\S$ measles } \\
\hline CAV-PV & & $4 \cdot 6$ & $<2$ & $<5$ & $<2$ & 320 \\
\hline Eluate & pH 4 & $0 \cdot 10$ & $<10$ & $<20$ & $<10$ & $<10$ \\
\hline Eluate & pH 3 & 0.19 & 80 & 40 & $<10$ & $<10$ \\
\hline Eluate & pH 2 & 0.02 & $<10$ & $<20$ & $<10$ & $<10$ \\
\hline
\end{tabular}

* Serum and synovial fluid samples, each containing a total amount of $20 \mathrm{mg} \mathrm{IgG}$, were used.

t Diluted to contain IgG between 4 and $6 \mathrm{~g} / 1$.

$\mp$ Each eluate concentrated to $100 \mu \mathrm{l}$.

$\$$ Consecutive reabsorptions with measles antigens, see text.

$\mathbf{C A V}=$ cell associated virus antigen; $\mathbf{P V}=$ purified extracellular virus antigen.

The bands of IgG of the antibody eluates showed only a partial correspondence to the oligoclonal IgG proteins of the unabsorbed SF. The IgG of the eluates from the serum showed a polyclonal distribution, but two weak zones corresponding to bands of IgG of the corresponding eluates from the SF were detected.

Immunoelectrophoretic analysis showed that the measles nucleoprotein antibody activity of the serum and the SF was recovered in the antibody eluates. The activity of this antibody was clearly higher in the eluates from the SF than from the serum (Fig. $1 b)$. Further, the measles neucloprotein antibody arc of the pH 4 eluate from the SF was bideflected, suggesting an association between this antibody and two separate zones of IgG detected by electrophoresis of the same eluate. The antibody arc of the pH 3 eluate was more evenly sloped and showed a maximum of precipitated protein in the basic IgG mobility zone.

Control absorption experiments with mumps virus, Sendai virus, and Newcastle disease virus antigens were carried out on separate SF samples from the patient. No decrease of the gammaglobulin content or of measles antibody titres was observed. The antibody eluates contained small or trace amounts of IgG. No bands of IgG were detected, except for a weak zone of $\mathrm{IgG}$ in the $\mathrm{pH} 2$ eluate after absorption with Newcastle disease virus.

Serum and SF samples, each in a volume containing $10 \mathrm{mg} \mathrm{IgG}$, from the control patient were absorbed with measles CAV antigen. The antibody eluates contained high titres of measles antibodies, but relatively low levels of IgG (Table 3). No decrease of the gamma globulin fraction was detectable by electrophoresis of the absorbed samples. The antibody eluates contained faintly staining gammaglobulins with a polyclonal pattern, and no bands of IgG were detected (Fig. 2a).

REPEATED ABSORPTION WITH MEASLES VIRUS ANTIGENS The absorption experiments described above failed to remove all measles antibody from the SF of the patient (Table 2). In order to obtain a complete absorption of measles antibody, the measles CAVabsorbed SF wsa further absorbed with a preparation of PV, then again with CAV, and finally with a mixture of PV and CAV antigens.

Removal of detectable measles antibody activities was observed after the final absorption (Table 2). No significant decrease of the oligoclonal IgG of the SF was, however, seen (Fig. 4a).

The antibody eluates obtained from the repeated absorption gave some additional information on the association between isolated IgG proteins and measles antibody activities. Thus one band of IgG with intermediate mobility and another more basic

Table 3 Absorption and isolation of measles virus antibodies from serum and synovial fluid $(S F)$ from the control patient with $R A$ with a polyclonal $\operatorname{Ig} G$ pattern of the $S F^{*}$

\begin{tabular}{|c|c|c|c|c|c|c|}
\hline & & \multirow{3}{*}{$\begin{array}{l}I g G \\
(g / l)\end{array}$} & \multicolumn{4}{|c|}{ Antibodies to } \\
\hline & & & \multicolumn{3}{|c|}{ Measles virus } & \multirow{2}{*}{ Adenovirus } \\
\hline & & & $H I$ & $H L I$ & $N C-C F$ & \\
\hline \multicolumn{2}{|c|}{$\begin{array}{l}\text { Serum } \\
\text { Serum absorbed }\end{array}$} & $4 \cdot 3$ & 320 & 40 & 40 & $<40$ \\
\hline \multicolumn{2}{|c|}{$\begin{array}{l}\text { Serum absorbed } \\
\text { measles CAV }\end{array}$} & $4 \cdot 3$ & $<40$ & $<40$ & $<10$ & $<40$ \\
\hline Eluate & pH 4 & 0.16 & 40 & 40 & $<10$ & $<10$ \\
\hline Eluate & pH 3 & 0.13 & 640 & 160 & 10 & $<10$ \\
\hline Eluate & pH 2 & 0.03 & 640 & $<80$ & 10 & $<10$ \\
\hline$S F$ & & $4 \cdot 3$ & 320 & 80 & 20 & $<40$ \\
\hline \multicolumn{7}{|c|}{ SF absorbed measles } \\
\hline CAV & & $4 \cdot 3$ & $<20$ & $<20$ & $<10$ & $<40$ \\
\hline Eluate & pH 4 & 0.19 & 160 & 80 & $<20$ & $<10$ \\
\hline Eluate & pH 3 & 0.29 & 2560 & 640 & $<20$ & $<10$ \\
\hline Eluate & pH 2 & 0.05 & 640 & 160 & $<20$ & $<10$ \\
\hline
\end{tabular}

* Serum and synovial fluid samples, each containing a total amount of $10 \mathrm{mg} \mathrm{IgG}$, were used. Experimental conditions otherwise as described for Table 2. 


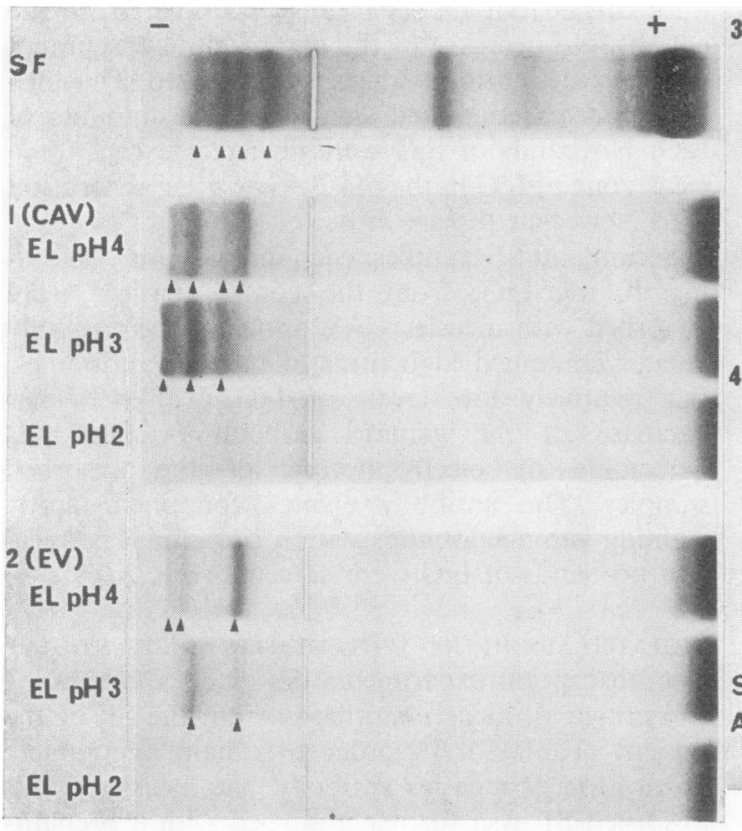

(a)

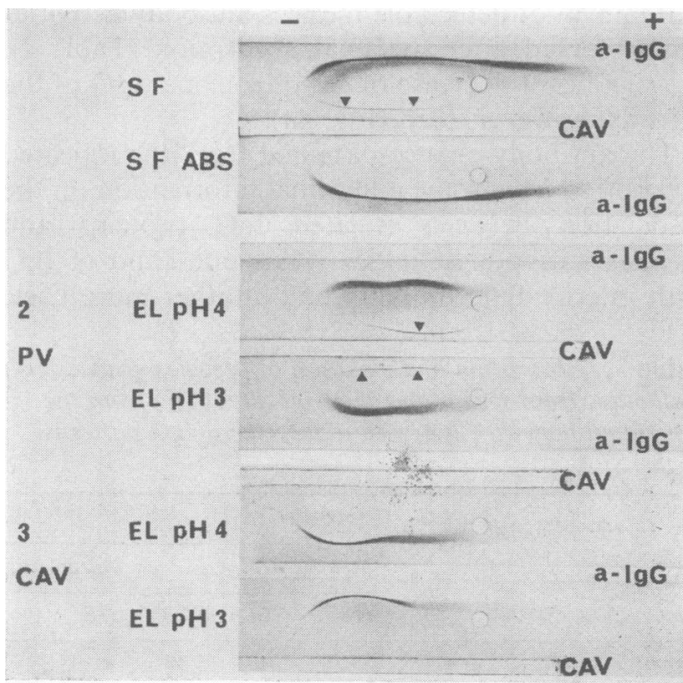

(b)

band, eluted at pH 4 and pH 3 respectively after the reabsorption with measles $\mathrm{PV}$ antigen, were each clearly associated with precipitating measles nucleoprotein activity. On the other hand, each of two markedly slow bands of IgG, eluted at $\mathrm{pH} 4$ and pH 3 after the reabsorption with measles CAV, seemed to be directed against other measles
3(CAV)

EL $\mathrm{pH} 4$

EL $\mathrm{pH} 3$

EL $\mathrm{pH} 2$

4 (CAV-EV)

EL pH 4

EL $\mathrm{pH} 3$

EL pH 2

$S F$

ABS 1-4

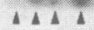

Fig. 4 (a) Repeated absorption-elution experiments with synovial fluid $(S F)$ from the patient. The figure shows electrophoresis of the unabsorbed SF at the top; antibody $\frac{}{\mathrm{D}}$ eluates at $\mathrm{pH} 4, \mathrm{pH} 3$, and $\mathrm{pH} 2$ obtained by absorption with measles cell associated virus (CAV) antigen (1), reabsorption with purified measles extracellular virus $(E V=P V$ in $(b)$ and in text $)(2)$, reabsorption with measles $C A V(2)$, and a final reabsorption with a mixture of $C A V$ and $E V$ antigens and finally absorbed $S F$ at the bottom (4). Arrowheads indicate positions of bands of IgG. (b) Immunoelectrophoresis of the unabsorbed and the finally absorbed $S F$ and of antibody eluates at $\mathrm{pH} 4$ and $\mathrm{pH} 3$ from the reabsorptions shown in $(a)$. The troughs were filled with antiserum to $\operatorname{IgG}(a-\operatorname{IgG})$ and with measles $C A V$ antigen. Measles nucleoprotein (NP) antibody arcs are marked by arrowheads.

antigens, since they did not carry precipitating nucleoprotein antibody activity (Fig. 4b). These eluates contained $\mathrm{HI}$ and HLI activities, but new NC-CF activity (Table 2).

\section{Discussion}

Our present results show that the SF of the patiento studied contained IgG measles antibodies o $\bar{P}$ restricted heterogeneity, of which at least two separate fractions were identified as antibody toD measles virus nucleoprotein. The markedly highes recovery of homogeneous measles antibody proteins 
from the SF than from the serum is consistent with a local synthesis in the affected tissue.

The general implications of the present findings with regard to the immunopathology of RA cannot be defined. Our patient was not a typical case of RA, with seronegative rheumatoid factor and suffering from disease mainly of large joints. Further, an oligoclonal IgG pattern of the SF is not a common finding in patients with RA and is in fact seen more frequently in psoriatic arthritis (Hedberg, 1971). Studies of materials from a larger number of patients are needed in order to see whether a local synthesis of oligoclonal measles antibodies is associated with a certain type of arthritis.

The relationship between the isolated virus antibody proteins and the total oligoclonal IgG of the SF was limited. Further, no decrease of the oligoclonal IgG of the SF was demonstrable by electrophoresis even when all serologically detectable measles antibody had been removed by repeated absorption. This indicates that only a small part of the oligoclonal IgG of the SF was associated with measles antibody activity, or that the antibody activity was partly blocked by immune complex formation in vivo. In other systems it has been established that under certain conditions a monoclonal immunoglobulin with antibody activity may remain electrophoretically homogeneous after immune complex formation but that its migration may be influenced by the charge of the antigen (Harboe and Følling, 1974). However, when the SF from our patient was separated by density gradient ultracentrifugation at $\mathrm{pH} 3$, known to dissociate immune complexes, no change in the eletrophoretic migration of the oligoclonal IgG proteins was observed (O. J. Mellbye, unpublished observations). Further, no anticomplementary reactions were observed in the serological studies of the SF, as might have been expected if immune complexes were present.

Local synthesis in the target organ of oligoclonal measles antibodies has previously been shown in patients with subacute sclerosing panencephalitis and in some patients with multiple sclerosis (Vandvik et al., 1976). In the former, most or all oligoclonal IgG proteins of the spinal fluid can be removed by the type of repeated measles virus absorption procedures used here. In multiple sclerosis, on the other hand, only a small part of the oligoclonal IgG of the spinal fluid can be absorbed. In this respect the results of measles antibody isolation experiments in multiple sclerosis and in the present patient are similar.

Our findings raise the question whether the local synthesis of measles antibodies is due to the presence in the affected tissue of measles virus immunogens. This is a tempting hypothesis in view of suggestions that arthritis may be due to a persistent viral infection.
Another explanation may be that the local antibody synthesis is due to a general nonspecific activation of preformed cell clones, e.g. due to the action of lymphokines or B-cell mitogens (Coutinho and Möller, 1973). In this instance the measles antibody producing cells may represent only a fraction of a number of different types of activated antibody producing cells.

Higher levels of SMA in the SF than in the serum and restriction of this antibody to a narrow zone of IgG in the SF suggests a local synthesis of SMA of restricted heterogeneity. This is of interest, since SMA appears to be antibody directed against actin (Gabbiani et al., 1973), a contractile protein which has recently been shown to be a constituent also of myxovirus particles (Wang et al., 1975). One might therefore speculate that immunization to measles virus in the joint is in some way associated with immunization to the actin component of the virus as well.

Drs. E. Munthe, Oslo, and B. Næs, Lillehammer, kindly provided materials from the patient. The study was supported by grants from the Norwegian Odd Fellow Order, The Oslo Multiple Sclerosis Society, and the Swedish Medical Research Council (Project no. 16x-116). The help from these organizations and the excellent technical assistance of Miss Ruth Nilsen and Miss Ylva Gollmar are gratefully acknowledged.

\section{References}

Albert, E. (1971). The pathogenesis of arthritis associated with viral hepatitis: complement-component studies. New England Journal of Medicine, 285, 185-189.

Coutinho, A., and Möller, G. (1973). B cell mitogenic properties of thymus-independent antigens. Nature ( New Biology), 245, 12-14.

Cremer, N. E., Hurwitz, D., Quismorio, F. P., Lenette, E. H., and Friou, G. J. (1974). Anti-viral antibodies in rheumatoid synovial fluid and cryoprecipitates. Clinical and Experimental Immunology, 18, 27-37.

Gabbiani, G., Ryan, G. B., Lamelin, J. P., Vassalli, P., Majuo, G., Bouvier, C. A., and Lüsher, E. R. (1973). Human smooth muscle autoantibody. Its identification as antiactin antibody and a study of its binding to "nonmuscular' cells. American Journal of Pathology, 72, 473-488.

Hannestad, K., and Mellbye, O. J. (1967). Rheumatoid factor in synovial effusions: local production and consumption. Clinical and Experimental Immunology, 2, 501-509.

Harboe, M., and Følling, I. (1974). Complex formation between monoclonal IgM and albumin. Scandinavian Journal of Immunology, 3, 51-60.

Hedberg, H. (1967). Studies on synovial fluid in arthritis. I. The total complement activity. Acta Medica Scandinavica, Suppl. 479. 
Hedberg, H. A. (1971). Faint narrow bands in the $\gamma$-region visible at agarose electrophoresis, The occurrence in various forms of arthritis. Annals of Clinical Research, 3, 281-285.

Hollinger, F. B., Sharp, J. T., Lidsky, M., and Rawls, W. (1971). Antibodies to viral antigens in systemic lupus erythematosus. Arthritis and Rheumatism, 14, 1-11.

Hurd, E. R., Dowdle, W., Casey, H., and Ziff, M. (1970). Virus antibody levels in systemic lupus erythematosus (SLE). Arthritis and Rheumatism, 13, 324-325.

Hurd, E. R., Dowdle, W., Casey, H., and Ziff, M. (1972). Virus antibody levels in systemic lupus erythematosus. Arthritis and Rheumatism, 15, 267-274.

Kalliomäki, J. L., and Halonen, P (1972). Antibody levels to parainfluenza, herpes simplex, zoster-varicella, cytomegalo virus, and measels virus in patients with connective tissue diseases. Annals of the Rheumatic Diseases, 31, 192-195.

Kalliomäki, J. L., and Halonen, P. (1975). The role of viruses in the aetiology of connective tissue diseases. Annals of Clinical Research, 7, 129-137.

Kalliomäki, J. L., Halonen, P., and Salmi, A. (1975). Virus antibodies in serum and synovial fluid of patients with rheumatoid arthritis and other connective tissue diseases. Annals of the Rheumatic Diseases, 34, 43-48.

Mancini, G., Carbonara, A. O., and Heremans, J. F. (1965). Immunochemical quantitation of antigens by single radial immunodiffusion. Immunochemistry, 2, 235-254.

Mellbye, O. J., and Natvig, J. B. (1970). Experimentally produced antibodies to the pepsin site of IgG due to untreated autologous IgG in immune complexes. Clinical and Experimental Immunology, 7, 257-267.

Mellbye, O. J., Næs, B., and Munthe, E. (1976). Complement and immunoglobulins in synovial fluid from synovectomized patients with rheumatoid arthritis. Annals of the Rheumatic Diseases, 35, 233-239.

Munthe, E., and Natvig, J. B. (1972). Immunoglobulin classes, subclasses, and complexes of IgG rheumatoid factor in rheumatoid plasma cells. Clinical and Experimental Immunology, 12, 55-70.

Norrby, E., and Gollmar, Y. (1972). Appearance and persistence of antibodies against different virus components after regular measles infections. Infection and Immunity, 6, 240-247.
Norrby, E., and Hammarskjöld, B. (1972). Structur components of measles virus. Microbios, 5, 17-29.

Norrby, E., Link, H., Olsson, J. E., Panelius, M., Salmi, and Vandvik, B. (1974). Comparison of antibodies against different viruses in cerebrospinal fluid and serum samples from patients with multiple sclerosis. Infection a Immunity, 10, 688-694.

Phillips, P. E., and Christian, C. L. (1970). Myxovirm antibody increases in human connective tissue disease Science, 168, 982-984.

Phillips, P. E., and Christian, C. L. (1973). Virus antibodiஓ in systemic lupus erythematosus and other connective tissue diseases. Annals of the Rheumatic Diseases, 32 450-456.

Smiley, J. D., Sachs, C., and Ziff, M. (1968). In vit synthesis of immunoglobulin by rheumatoid synovial membrane. Journal of Clinical Investigation, 47, 624-632?

Smith, J. W., and Sanford, J. P. (1967). Viral arthritis. Annats of Internal Medicine, 67, 651-659.

Vandvik, B., and Degré, M. (1975). Measles virus antibodiês in serum and cerebrospinal fluid in patients with multipfe sclerosis and other neurological disorders, with special reference to measles antibody synthesis within the centrat nervous system. Journal of Neurological Sciences, $2 \frac{8}{4}$ 201-219.

Vandvik, B., and Norrby, E. (1973). Oligoclonal IgG anț body response in the central nervous system to differem measles virus antigens in subacute sclerosing panencephalitis. Proceedings of the National Academy of Sciencies of the USA, 70, 1060-1063.

Vandvik, B., Norrby, E., Nordal, H. J., and Degré, M. (1976 Oligoclonal measles virus-specific IgG antibodies isolat from cerebrospinal fluids, brain extracts, and sera from patients with subacute sclerosing panencephalitis an multiple sclerosis. Scandinavian Journal of Immunology, 5 979-992.

Wang, E., Wolf, B. A., Lamb, R. A., Choppin, P. W. ane Goldberg, A. R. (1975). The presence of actin in enveloped viruses. Journal of Cell Biology, 67, a445.

Yanez, J. E., Thompson, G. R., Mikkelsen, W. M., and Bartholomew, L. E. (1966). Rubella arthritis. Annals औ Internal Medicine, 64, 772-777. 